\title{
RESPIRATORY DISEASES AND \\ PNEUMONIAMANIFESTOF SEASONAL VARIABILITY AN EXAMPLE FROM NITRA REGION IN SLOVAKIA
}

\author{
Magula, D. \\ Specialized Hospital of St. ZoerardusZobor, Nitra, Slovakia
}

\begin{abstract}
The aim of this study was to analyze the incidence of some respiratory diseases in outpatient's pneumology departments along three years period and point out seasonal variation in these diseases. The number of examined ambulatory patients suffered from all causes of respiratory diseases and pneumonia on monthly basis were applied to create a timeseries analysis in numerical and graphical output of data. Significant differences in all followed diseases between winter season and summer season were observed. These data are in accordance with data of other authors and epidemiological surveys on long year's basis. Possible reasons of these observations are discussed, and it may speculate about seasonally driven viral circulation. Deficiency in vitamin D levels in wintertime is another possible reason for winter peak in the incidence of respiratory diseases. Our results can aid not only in effective allocation of resources and services but can be helpful for better understanding of respiratory epidemiology, respiratory pathology with potential role of vitamin $D$ in its possible improvement, especially in wintertime.
\end{abstract}

Keywords: respiratory diseases - seasonality - pneumonia - vitamin D

\section{INTRODUCTION}

Seasonality is a common feature of communicable diseases, inclusive of respiratory diseases as well. Studies concerning this problem in the field of respiratory diseases are still rare, most of them are studies observational[6,9]. None results were published from our surrounding regions. Our results could contribute for better identification of these seasonal trends and could be a basis for following research in this field. Especially the relationship between vitamin D status and overall health, respiratory diseases including, could be an interesting topic to be investigated in the future research. 


\section{MATERIALS ANDMETHODS}

The data concerning the rate of examined patients with some types of respiratory diseases were extracted from databases of outpatient's pneumology departments situated in hospital specialized in respiratory diseases counting the catchment area about 140 thousands inhabitants of Nitra region (Slovakia). The data were extracted by retrospective method along three years period $(2008$ - 2010) each month consecutively and the time-series analyses were performed. The rate in all visits of patients in outpatient's pneumology departments and pneumonia were followed-up. Positive chest $\mathrm{X}$-rays finding was the criterion to establish the diagnosis of pneumonia. The results are presented in graphical time-serieslines/columns and discussed next to observations of other authors.

\section{RESULTS}

In graphic presentation the results of original three-year observation $2008-2010$ by the months and rates of examined outpatients' for all respiratory diseases and for pneumonia were recorded.

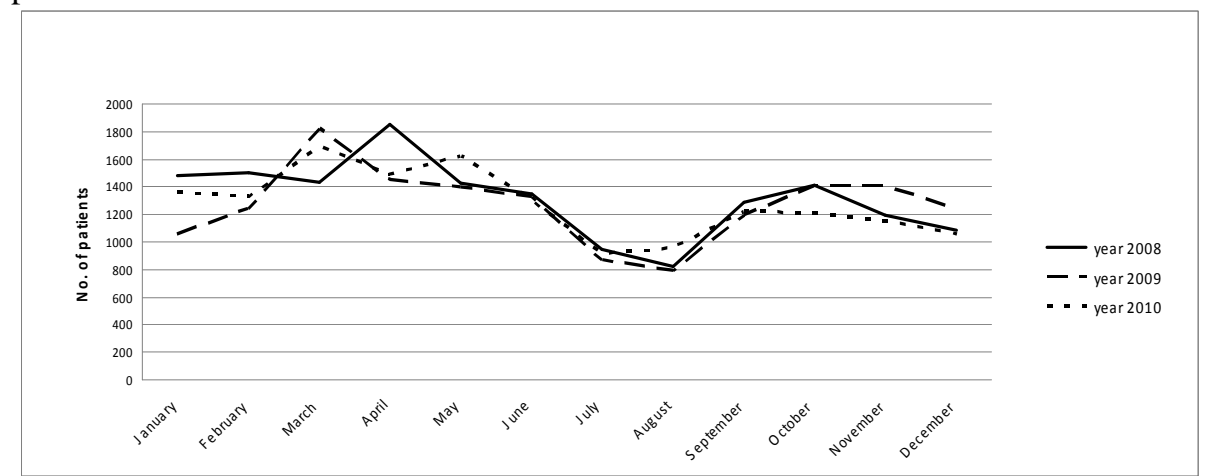

Figure 1. Seasonal variability in rate of all patients with respiratory disorders inpneumology outpatient's departments within years 2008-2010

Over three-years period there were peak in rate of examined patients in March $(n=4941$ patients) and low rate in August $(n=2570$ patients). Thus the number of visits for all respiratory disorders was almost twofold higher in March in comparison to August (1.92-fold higher). 


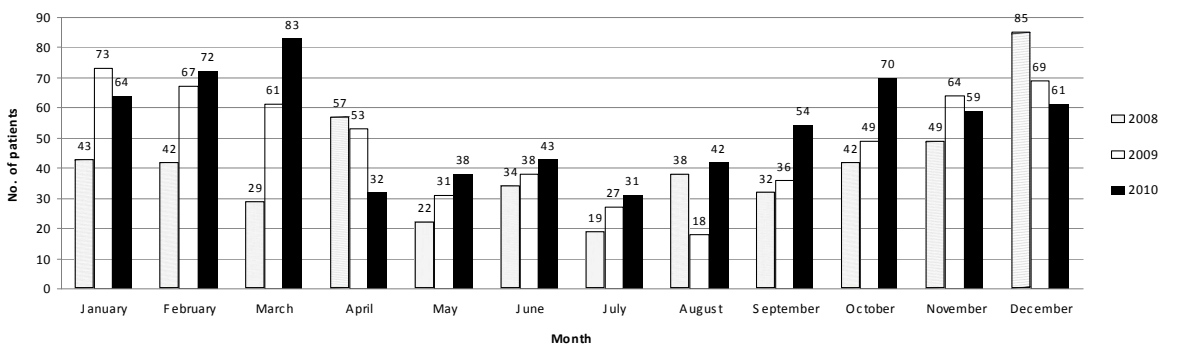

Figure 2. Seasonal variability in rate of patients with documented pneumonia in pneumology outpatient's departments within years 2008-2010

The high rate inpneumonia within three-year period were documented in December $(n=215$ pts with pneumonia), low rate in July $(n=77$ pts). Thus present 2.79-fold higher incidence of pneumonia in December in comparison to July. The incidence of pneumonia distributed by season of year (three months period) is documented in Tab. 1.

Table 1. Distribution of pneumonia cases by the seasons within period of three years 2008-2010 and statistical analysis

\begin{tabular}{|l|l|l|l|l|}
\hline & \multicolumn{1}{|c|}{$\begin{array}{c}\text { Winter } \\
(\mathbf{W i})^{*}\end{array}$} & $\begin{array}{c}\text { Spring } \\
(\mathbf{S p})^{*}\end{array}$ & \multicolumn{1}{c|}{$\begin{array}{c}\text { Summer } \\
(\mathbf{S u})^{*}\end{array}$} & $\begin{array}{c}\text { Autumn } \\
(\mathbf{A u})^{*}\end{array}$ \\
\hline $\begin{array}{l}\text { All cases of } \\
\text { pneumoniae in } \\
2008-2010\end{array}$ & $\mathrm{n}=576$ & $\mathrm{n}=406$ & $\mathrm{n}=290$ & $\mathrm{n}=455$ \\
\hline $\begin{array}{l}\text { Monthly } \\
\begin{array}{l}\text { average of cases } \\
\pm \text { SD }\end{array}\end{array}$ & $64.0 \pm 13.9$ & $45.1 \pm 19.7$ & $32.2 \pm 9.3$ & $50.6 \pm 12.6$ \\
\hline
\end{tabular}

*Winter (Wi):December - February, Spring (Sp): March - May, Summer (Su): June - August, Autumn (Au): September - November

Statistical analysis(Student T-test)

$\mathrm{Wi} / \mathrm{Sp} \mathrm{p}=0.05213$

$\mathrm{Wi} / \mathrm{Su} \mathrm{p}=0.00026 * * *$

$\mathrm{Wi} / \mathrm{Au} \mathrm{p}=0.07693$

$\mathrm{Sp} / \mathrm{Su} \mathrm{p}=0.09012$

$\mathrm{Sp} / \mathrm{Au} \mathrm{p}=0.53783$

$\mathrm{Su} / \mathrm{Au} \mathrm{p}=0.01016 *$

Significant statistical difference were found between summer and winter season ( $\mathrm{p}=0.00026)$ and summer and autumn season $(\mathrm{p}=0.01016)$. Other seasonal comparisons didn't achieve statistical significance. 


\section{DISCUSSION}

Research papers discussed on problems of seasonal variation of incidence in respiratory diseases are still today rare and health services research is in its scientific infancy. One aspect of it's that epidemiology is not regarded as a science with the predictive accuracy. Despite of this using time series analysis in our analysis could show the trends in incidence of all respiratory disease along all seasons of the year. In our regions these analysis belong to the first published data in this field. Similar research is known from Ontario (Canada). Moineddin et al. published similar retrospective, cross-sectional time series analysis in primary care visits for respiratory diseases, for a 10-year period in a total of 66 million visits with respiratory diseases. Overall respiratory primary care visits show clear seasonal variation, peaks in incidence occurs annually from the winter to early spring, corresponding to influenza and respiratory syncytial virus circulation. Winter visits were threefold higher than summer troughs. Also in specific respiratory diseases as bronchial asthma, chronic obstructive pulmonary disease, respiratory infections and pneumonia were documented very strong seasonal effects[6]. Similar trends in seasonal variation of respiratory diseases were described in hospital admission by same author's team in Canada for specific respiratory disease entities, including pneumonia[3,9]. Müller-Pebody (2006) show seasonality in lower- respiratory tract infection in hospital admission in the elder people with the ambition to reach the characteristics of causative organisms. Most notably respiratory syncytial virus (RSV) and Bordetella pertussis have a role in causing LRI in these elder patients [7]. Noah found that in England and Wales RSV and parainfluenza 1 and 2 display marked wintertime excess [8]. The most common explanation for the seasonality of respiratory infections is that human congregate indoors in the winter, thus increase the chance for contagion[1].

Different point of view to seasonal variation of epidemic influenza was introduced in 1981by Hope-Simpson based upon high incidence of influenza in wintertime in northern geographical latitude (and simultaneously low incidence in southern latitude) and inversely, upon ten years databases of World Health Organization. This so called ,seasonal stimulus“(known now as Hope-Simpson phenomenon) was given to relationship to different intensity of solar radiation along the year. He theorized that humans might have a physiological system directly dependent on solar radiation triggering the formation of $D$ vitamin in the skin from prehormone $\mathrm{m}$ cholecalciferol and that improves innate immunity around the summer solstice but impairs it in the winter. In the winter the regular deficiency in vitamin D is recorded [2].

Currently more and more papers on deficiency in vitamin D in relationship to incidence of respiratory diseaseand/orworsening in pulmonary function were released.The inverse correlation between levels of vitamin D and incidence of respiratory disease were published.

Hyppönen and co-workers measured 25-hydroxyvitamin D in 7437whites from the 1958 British birth cohort when they were 45 year old. The prevalence of hypovitaminosis D was highest duringthe winter and spring, when $25(\mathrm{OH})$ Dconcentrations under $75 \mathrm{nmol} / \mathrm{L}$ in the winter were found in $87.1 \%$ of participants, 
in the spring $60.9 \%$. The highest levels of D vitamin were found in September, the lowest ones in February - March, every year during research conducted within period $2002-2004$ [4].

There were more papers reported on inverse relation between incidence of respiratory diseases and levels of vitamin D. Eight hundred of young Finnish men serving on a military base inFinland were enrolled in study in which subjects with serum 25(OH)Dconcentrations_ lower than 40nmol/1 had significantly $(P=0.004)$ more days of absence from duty due to respiratory infection (median:4; quartile 1-quartile $3: 2-6)$ than did control subjects $(2 ; 0-4)$, incidence rate ratio 1.63 ; $95 \%$ CI: $1.15,2.24[5]$.

These coincidences and new views are open for future research.

\section{CONCLUSIONS}

In our study significant seasonal differences in visits of all respiratory diseases and pneumonia in outpatient's department were recorded. These data are in correspondence with findings of other authors. This can be important from economical and logistic point of view for planningallocation. From medical point of view the higher circulation of viruses as potential causative relationship to all respiratory diseases (implying pneumonia) in the winter is thought, but new emerging relationships, especially to vitamin D status are hypothesized. The number of paper on last mentioned relationships is rising significantly. These new aspects and coincidences are open for future research activities with potential beneficial effects of vitamin D.

Acknowledgement: This paper is dedicated to the memory of my sister Assoc. Prof. PharmDr. LíviaMagulová, PhD., an excellent Slovak clinical pharmacist.

\section{REFERENCES}

1. ANDREWES, C.L.: The Common Cold. New York: Norton,1965, 187p.

2. CANNELL, J.J. - VIETH, R. - UMHAU, J.C. et al.: Epidemic influenza and vitamin D. In Epidemiol Infect, 134, 2006, p. 1129-1140.

3. CRIGHTON, E.J. - MOINEDDIN, R. - MAMDANI, M. - UPSHUR, R.E.G.: Influenza and pneumonia hospitalizations in Ontario: a time-series analysis. In Epidemiol Infect, 132, 2004, p.1167-1174.

4. HYPPÖNEN, E. - POWER, CH.: Hypovitaminosis D in British adults at age $45 \mathrm{y}$ : nationwide cohort study of dietary and lifestyle predictors. In Am J Clin Nutr, 85, 2007, p.860-868.

5. LAAKSI, I. -RUOHOLA, J.P. - TUOHIMAA, P. et al.: An association of serum vitamin D concentrations $<40 \mathrm{nmol} / 1$ with acute respiratory tract infection in young Finnish men. Am J Clin Nutr, vol. 86, 2007, p.714-717.

6. MOINEDDIN, R. - NIE, J.X. - DOMB, G., et al.: Seasonality of primary care utilization for respiratory diseases in Ontario: A time series analysis. In BMC Health Services Research [online]. 8., 2008, 160 p., doi.:10.1186/1472-6963-8-160 [accessed30.11.2010]. Available on internet: <http:// www.biomedcentral.com/1472-6963/8/160) 
7. MÜLLER-PEBODY, B. - CROWCROFT, N.S. - ZAMBON, M.C. - EDMUNDS, W. J.: Modelling hospital admissions for lower respiratory tract infections in the elderly in England. In Epidemiol Infect, vol. 134, 2006, p. 1150-1157

8. NOAH, N.D.: Cyclical patterns and predictability in infection. In Epidemiology and Infection, vol. 102, 1989, p. 175-190.

9. UPSHUR, R.E.G. - MOINEDDIN, R. - CRIGHTON, E. et al.: Simplicity within complexity: Seasonality and predictability of hospital admission in the province of Ontario 1988-2001, a population-based analysis. BMC Health Services Research [online]. 5, 2005, 13, doi.:10.1186/1472-6963-5-13 [accessed30.11.2010]. Available on internet: <http:// www.biomedcentral.com/1472-6963/5/13)

Registered:October, 2011

Accepted:January, 2012
MUDr. Daniel Magula, CSc. Specialized Hospital of St. Zoerardus Zobor Kláštorská 134 94988 Nitra magula@snzobor.sk

\title{
RESPIRAČNÉ CHOROBY A PNEUMÓNIE VYKAZUJÚ SEZÓNNU VARIABILITU PRÍKLAD Z REGIÓNU NITRA
}

\author{
Magula, D.
}

\author{
Špecializovaná nemocnica sv. Svorada, Nitra
}

Ciel'om štúdie bolo zanalyzovat' výskyt niektorých respiračných chorôb u ambulantných pacientov $v$ plúcnych ambulanciách počas trojročnej periódy a poukázat' na sezónnu variabilitu v prípade týchto chorôb. Počty vyšetrených ambulantných pacientovso všetkými prípadmi respiračných chorôb a osobitne pneumóniami na mesačnej bázeboli podkladom pre vytvorenie časových analýz v číselnom aj grafickom výstupe. Zistili sa významné odchýlky $\mathrm{v}$ incidencii všetkých respiračných ochorení a pneumónií medzi zimnou a letnou sezónou. Počet ambulantných návštev pre všetky respiračné choroby počas troch rokov sledovania (2008 - 2010) bol v mesiaci marec viac ako 1,92-násobne vyšší ako v mesiaci august. Počet ambulantne dokumentovaných pneumónií počas rovnakého obdobia sledovania bol v mesiaci december 2,79-násobne vyšší ako v mesiaci júl. Distribúcia počtu pneumónií bola v zimnom období (december - február) významne vyššia aj pri štatistickom porovnaní (StudentovT-test, $\mathrm{p}=0,00026$ ) voči letnému obdobiu (jún - august). Tieto dáta sú v súhlase s dátami iných autorov a dátami epidemiologických štúdiízhromaždenými na dlhoročnej báze. Ako príčinnú súvislost’ tejto variability uvádzajú niektorí autori vy̌ššiu cirkuláciu vírusov v populácii v zimnom období. Iní autori dávajú takéto sezónne zmeny do priamej súvislosti s ročnou variabilitou hladín vitamínu $\mathrm{D}$ v sére, ktorá je pravidelne najnižšia v zimnom a skorom jarnom období. Výsledky našej observačnej štúdie tieto zistenia sezónnej variability respiračných chorôb a výskytu pneumónií potvrdzujú. Môžu poslúžit' pre efektívnejšiu alokáciu zdrojov v zdravotnom systéme v priebehu roka z pohl'adu ekonomického a logistického. Z pohl'adu medicínskeho môžu byt' podkladom pre lepšie pochopenie respiračnej epidemiológie a respiračnej patológie, s potenciálnou prospešnou úlohou vitamínu $\mathrm{D}$ v týchto procesoch. Tieto novšie zistené súvislosti sú zároveň aj podnetom pre d’alšie výskumy venujúce sa tejto problematike.

Acta Fac. Pharm. Univ. Comen., Suppl., 2012, VI, p. 52 - 57. 